\title{
ANALISIS PENGARUH PERUBAHAN PENGGUNAAN LAHAN TERHADAP RETENSI POTENSIAL AIR OLEH TANAH PADA KEJADIAN HUJAN SESAAT (STUDI KASUS PERUBAHAN PENGGUNAAN LAHAN DI DAS GARANG JAWA TENGAH)
}

\author{
Ahmad Cahyadi' ${ }^{1)}$, Ardila Yananto ${ }^{2)}$, Muhammad Sufwandika Wijaya ${ }^{3)}$, Henky Nugraha ${ }^{4)}$ \\ ${ }^{1}$ Magister Perencanaan Pengelolaan Pesisir dan Daerah Aliran Sungai (MPPDAS) \\ Fakultas Geografi Universitas Gadjah Mada Yogyakarta \\ ${ }^{2,3}$ Jurusan Kartografi dan Penginderaan Jauh Fakultas Geografi Universitas Gadjah Mada \\ ${ }^{4}$ Jurusan Geografi Lingkungan Fakultas Geografi Universitas Gadjah Mada \\ Email: ${ }^{1}$ ahya.edelweiss@ gmail.com
}

\begin{abstract}
Abstrak
Tujuan penelitian ini adalah untuk mengetahui pengaruh perubahan penggunaan lahan di DAS Garang Jawa Tengah Tahun 1994, 2001 dan 2008 terhadap retensi potensial maksimum air oleh tanah pada kejadian hujan sesaat (storm rainfall). Metode yang digunakan adalah metode SCS yang dikembangkan oleh The Soil Conservation Services. Data yang digunakan adalah data penggunaan lahan yang diekstrak dari citra Tahun 1994, citra 2001 dan citra 2008 menggunakan software ENVI dan peta tanah DAS Garang skala semi detail. Hasil penelitian menunjukkan bahwa retensi potensial maksimum air oleh tanah pada kejadian hujan sesaat di DAS Garang semakin menurun. Hal ini disebabkan semakin luasnya lahan terbangun dan semakin sempitnya lahan non-terbangun. Kondisi ini akan menyebabkan imbuhan terhadap airtanah di DAS Garang semakin kecil dan debit puncak banjir akan semakin besar.
\end{abstract}

Kata Kunci: Hujan Sesaat, Perubahan Penggunaan Lahan, Retensi Potensial

\section{PENDAHULUAN}

Pertambahan penduduk yang terus terjadi akan menyebabkan kebutuhan akan ruang semakin besar (Soerjani dkk, 2008). Selain disebabkan oleh pertambahan penduduk oleh kelahiran yang lebih banyak dibandingkan dengan kematian, suatu perkotaan yang memiliki daya tarik yang tinggi menyebabkan pertambahan penduduk melalui arus migrasi dari desa ke kota. Kondisi ini juga akan menyebabkan terjadinya perluasan lahan terbangun sehingga terjadi urban sprawl. Kondisi juga terjadi di wilayah perkotaan Semarang.

Perkembangan wilayah perkotaan menyebabkan banyaknya perubahan penggunaan lahan dari lahan non-terbangun menjadi lahan terbangun (Brath dkk, 2006). Kondisi ini secara hidrologis dapat menyebabkan terjadinya gangguan terhadap hidrologi. Butler and Davies (2011) menjelaskan bahwa perubahan penggunaan lahan dari lahan non-terbangun menjadi lahan terbangun akan menyebabkan terjadinya peningkatan aliran permukaan dan semakin sedikitnya airtanah. Hal ini terjadi karena jumlah air yang meresap semakin sedikit dan berubah menjadi aliran permukaan (Gambar 1).

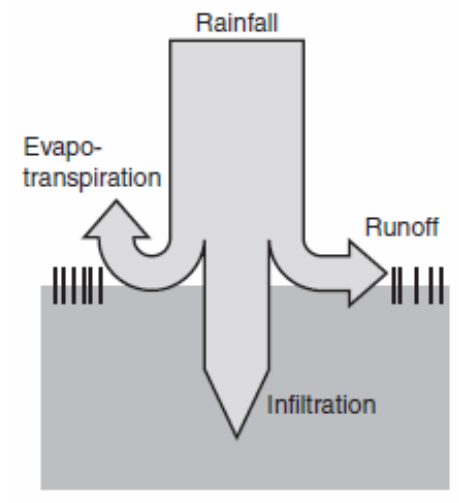

(a) Pre-urbanisation

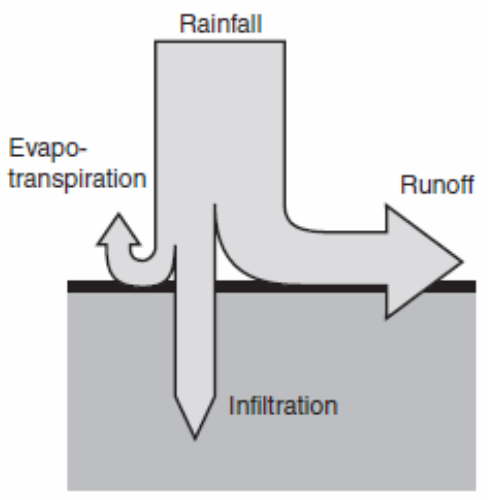

(b) Post-urbanisation

Gambar 1. Perubahan Siklus Hidrologi Akibat Perubahan Penggunaan Lahan (Butler and Davies, 2011) 
Jumlah air permukaan yang semakin banyak menyebabkan potensi terjadinya banjir akan semakin besar (Maryono, 2007). Kondisi ini juga terjadi di beberapa kota di Indonesia (Kodoatie dan Sugiyanto, 2002). Salah satu kota yang sering mengalami banjir adalah Kota Semarang, khususnya wilayah yang berada di DAS Garang (Suhandini, 2012). Kejadian Banjir di DAS Garang Tahun 1987-2008 sebanyak 40 kali, di mana banjir yang terjadi diklasifikasikan sebagai kejadian banjir bandang.

Kejadian banjir bandang pada periode Tahun 1987-1997 sebanyak 24 kali, di mana banjir tertinggi memiliki debit 1.103,73 $\mathrm{m}^{3}$ /detik (kejadian banjir Tahun 1990), sedangkan pada periode Tahun 1998-2008 terjadi 16 kali banjir bandang, di mana debit tertinggi mencapai 893,22 $\mathrm{m}^{3} /$ detik ( kejadian banjir Tahun 2006). Selain itu, banjir bandang telah menyebabkan terjadinya korban jiwa dan kerugian harta benda. Windarto (2010) menyebutkan bahwa kejadian banjir pada Tanggal 25 Januari 1990 telah menyebabkan 45 orang meninggal dan menyebabkan terjadinya kerugian sekitar 8,5 milyar rupiah. Oleh karena intensitas kejadian banjir bandang di DAS Garang sangat tinggi (rata-rata 2 kali dalam setahun), maka diperlukan analisis terkait dengan faktor-faktor yang dapat menyebabkan semakin tingginya potensi terjadinya banjir bandang. Salah satunya adalah kajian tentang perubahan penggunaan lahan dan pengaruhnya terhadap kemampuan retensi air oleh tanah.

Penelitian ini bertujuan untuk mengetahui pengaruh perubahan penggunaan lahan di DAS Garang Jawa Tengah Tahun 1994, 2001 dan 2008 terhadap retensi potensial maksimum air oleh tanah pada kejadian hujan sesaat (storm rainfall). Kapasitas retensi yang dimaksud terdiri dari tiga skenario, yakni pada kondisi tanah kering, normal dan kering. Hal ini dilakukan karena jumlah retensi air oleh tanah pada ketiga kondisi tersebut berbeda (Triatmodjo, 2009).

\section{WILAYAH KAJIAN}

Wilayah penelitian yang digunakan dalam penelitian ini adalah DAS Garang. Secara astronomis, DAS Garang terletak di antara $110^{\circ} 15^{\prime} 43^{\prime}$ BT - $110^{\circ} 30^{\prime} 37^{\prime}$ BT dan 6 $6^{\circ} 54^{\prime} 49^{\prime \prime}$ LS - 7 $1^{\circ} 11^{\prime}$ 51" LS. Secara administratif DAS Garang meliputi tiga kabupaten dan satu kota madya, yaitu; Kabupaten Demak, wilayah Kabupaten Kendal, wilayah Kabupaten Semarang serta wilayah Kotamadya Semarang. Lokasi wilayah kajian ditunjukkan Gambar 2.

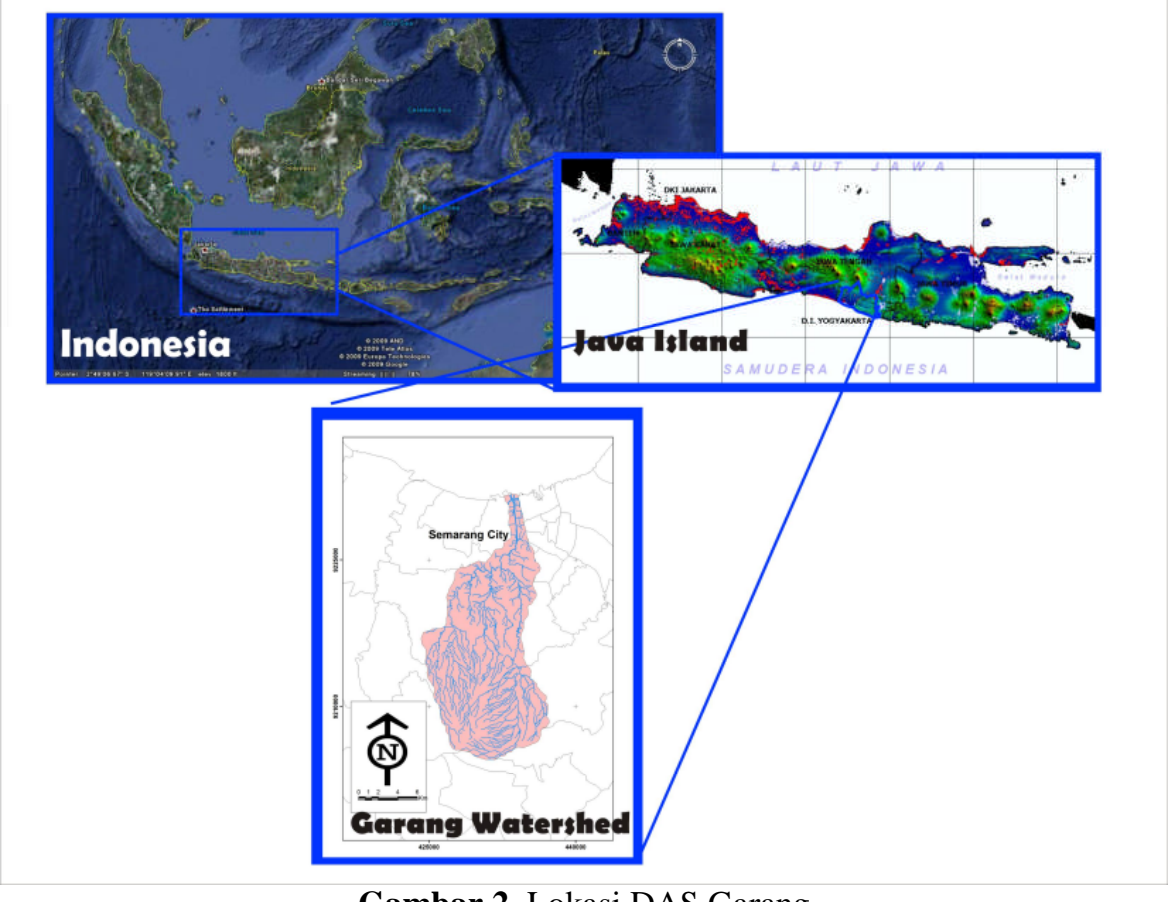

Gambar 2. Lokasi DAS Garang

\section{METODE PENELITIAN}

\section{A. Data yang Digunakan}

Data yang digunakan dalam penelitian ini meliputi peta Rupa Bumi Indonesia (RBI), Citra Landsat TM Tahun 1994, Landsat ETM Tahun 2001, dan citra ALOS AVNIR Tahun 2008, dan peta tanah skala semi detail. Peta RBI skala 1:25.000 terbitan BAKOSURTANAL digunakan untuk melakukan pembatasan DAS 
Garang. Peta penggunaan ahan dan peta tanah digunakan untuk menentukan nilai curve number $(\mathrm{CN})$ yang digunakan dalam perhitungan kapasitas retensi maksimum air oleh tanah.

\section{B. Analisis Perubahan Penggunaan Lahan}

Analisis perubahan penggunaan lahan dilakukan dengan membandingkan luas pada masing-masing penggunaan lahan pada citra multi-temporal yang digunakan dalam penelitian ini. Peta penggunaan lahan dihasilkan dari pengolahan citra secara digital dari Citra Landsat TM Tahun 1994, Landsat ETM Tahun 2001, dan citra ALOS AVNIR Tahun 2008 dengan menggunakan software ENVI 4.5. Sistem informasi geografis sangat berperan dalam pehitungan luas masing-masing penggunaan lahan.

\section{Perhitungan Jumlah Retensi Maksimum Air Oleh Tanah}

Metode yang digunakan untuk menghitung kapasitas retensi maksimum air oleh tanah adalah metode SCS. Metode SCS dikembangkan oleh The Soil Conservation Services pada Tahun 1972. Metode ini digunakan untuk menghitung ketebalan hujan efektif atau ketebalan dari surface run off yang terbentuk pada suatu kejadian hujan serta kapasitas retensi air oleh tanah pada kondisi tanah kering, normal dan jenuh. Metode ini hanya dapat digunakan untuk menghitung ketebalan hujan efektif atau surface run off yang dihasilkan oleh hujan sesaat atau hujan harian, serta perhitungan kapasitas retensi air oleh tanah. Metode ini tidak dapat digunakan untuk menentukan ketebalan run off dari hujan bulanan atau tahunan. Langkah perhitungan yang dilakukan adalah sebagai berikut:

\section{Menentukan Nilai $\mathbf{C N}$}

Nilai CN ditentukan dengan langkah berikut ini:

a. Menentukan Klasifikasi Tanah Secara Hidrologi

Klasifikasi Tanah secara hidrologi dibedakan menjadi 4 kelompok yaitu:

1) A $\rightarrow$ karakteristik tanah dengan tekstur pasiran \& profil dalam, dengan laju infiltrasi > $0.75 \mathrm{~cm} / \mathrm{jam}$.

2) $\mathrm{B} \rightarrow$ tektur tanah pasir bergeluh \& profil dangkal.

3) C $\rightarrow$ tektur tanah lempung bergeluh \& kandungan BO sedikit,

4) $\mathrm{D} \rightarrow$ tekstur tanah lempung \& laju infiltrasi $<0.15 \mathrm{~cm} / \mathrm{jam}$.

b. Menentukan Jenis Penggunaan Lahan berdasarkan peta penggunaan lahan.

c. Menghitung Nilai CN pada Kondisi Normal (Hujan 5 Hari Sebelumnya Antara 36-53 mm). Nilai CN pada kondisi normal ditentukan dengan tabel berikut ini:

Tabel 1. Nilai Curve Number pada Berbagai Penggunaan Lahan dan karakteristik Tanah

\begin{tabular}{|r|l|r|r|r|r|}
\hline \multirow{2}{*}{ No } & \multirow{2}{*}{ Deskripsi Penutup Lahan } & \multicolumn{4}{|c|}{ Kelompok Hidrologi Tanah } \\
\cline { 3 - 7 } & & A & B & C & \multicolumn{1}{l|}{ D } \\
\hline \multirow{2}{*}{1} & Hutan & 25 & 55 & 70 & 77 \\
\cline { 3 - 7 } & & 30 & 58 & 72 & 78 \\
\cline { 3 - 7 } & & 25 & 55 & 70 & 77 \\
\hline 2 & Padang rumput & 36 & 60 & 73 & 78 \\
\hline \multirow{2}{*}{3} & Kawasan industri dan perparkiran & 90 & 93 & 94 & 94 \\
\cline { 3 - 7 } & kedap air & 90 & 93 & 94 & 95 \\
\hline 4 & Kawasan Perumahan & 60 & 74 & 83 & 87 \\
\hline 5 & Lahan Terbuka & 72 & 82 & 88 & 90 \\
\cline { 3 - 7 } & & 77 & 86 & 91 & 94 \\
\hline 6 & Lahan Pertanian Tertutup Tanaman & 52 & 68 & 79 & 84 \\
\hline 7 & Lahan Pertanian Tertutup Tanaman & 64 & 75 & 83 & 87 \\
\hline 8 & Tubuh Perairan & 98 & 98 & 98 & 98 \\
\hline
\end{tabular}

Sumber: Ragan dan Jackson, 1980; Slack dan Welch, 1980; Bondelid, 1982

d. Menghitung Nilai CN pada kondisi Kering dan Basah (bila diperlukan) 
Langkah sebelumnya (1 C) menghasilkan nilai CN pada kondisi normal (CN II), yaitu ketika hujan 5 hari sebelumnya antara 36-53 mm. Apabila hujan kurang dari $36 \mathrm{~mm}$ (kondisi kering) atau lebih dari $53 \mathrm{~mm}$ (kondisi basah/jenuh) maka diperlukan perhitungan nilai $\mathrm{CN}$ dengan rumus-rumus sebagai berikut:

Tabel 2. Tabel Penentuan Kondisi Tanah Kering, Normal/Sedang dan Jenuh/Basah

\begin{tabular}{|l|l|}
\hline \multicolumn{1}{|c|}{ Kelompok AMC } & Jumlah hujan 5 hari sebelumnya (cm) \\
\hline Kelompok I (kering) & $<3,6$ \\
\hline Kelompok II (sedang) & $3,6-5,3$ \\
\hline Kelompok III (basah) & $>5,3$ \\
\hline \multicolumn{2}{|c|}{ Sumber: McCuen, 1982 }
\end{tabular}

1) Rumus CN pada Kondisi Kering (CN I):

$$
\mathrm{CN}(\mathrm{I})=(4,2 \mathrm{CN}(\mathrm{II})) /(10-0,058 \mathrm{CN}(\mathrm{II}))
$$

2) Rumus CN pada Kondisi Basah (CN III):

$$
\mathrm{CN}(\mathrm{III})=(23 \mathrm{CN}(\mathrm{II})) /(10+0,13 \mathrm{CN}(\mathrm{II}))
$$

\section{Menentukan Nilai CN Wilayah}

Nilai CN wilayah ditentukan dengan rerata timbang sebagai berikut:

$$
\mathrm{CN}=\left(\mathrm{CN}_{1} \mathrm{~A}_{1}+\mathrm{CN}_{2} \mathrm{~A}_{2}+\ldots .+\mathrm{CN}_{\mathrm{n}} \mathrm{A}_{\mathrm{n}}\right) /\left(\mathrm{A}_{1}+\mathrm{A}_{2}+\ldots .+\mathrm{A}_{\mathrm{n}}\right)
$$

Keterangan:

$\mathrm{CN}=$ Curve Number

$\mathrm{A}$ = Luas masing-masing poligon yang diwakili satu nilai $\mathrm{CN}$

\section{Menentukan Nilai Tebal S}

Tebal S dihitung dengan Rumus:

Keterangan:

$$
\mathrm{S}=(25.400 / \mathrm{CN})-254
$$

Tebal $\mathrm{S}=$ Tebal Retensi Potensial Maksimum Air Oleh Tanah (mm)

$\mathrm{CN}=$ Curve Number sesuai dengan kondisi tanah (berdasarkan jumlah hujan 5 hari sebelumnya). $\quad \mathrm{CN}$ yang digunakan sesuai dengan kondisi kelembaban tanah.

\section{Menentukan Nilai S}

Nilai S (retensi potensial maksimum air oleh tanah) dihitung dengan rumus:

\section{Nilai $\mathrm{S}=$ Tebal $\mathrm{S} \times$ Luas DAS}

Perhitungan menggunakan rumus di atas harus dilakukan dengan Tebal $\mathrm{S}$ menggunakan ukuran meter $(\mathrm{m})$, dan luas DAS dengan ukuran meter persegi $\left(\mathrm{m}^{2}\right)$. Berdasarkan perhitungan tersebut, maka akan diperoleh volume retensi potensial maksimum air oleh tanah pada masingmasing tahun yang dianalisis.

\section{HASIL DAN PEMBAHASAN}

Hasil analisis perubahan penggunaan/penutup lahan menggunakan citra multi temporal menunjukkan bahwa beberapa penggunaan/penutup lahan mengalami penambahan cukup pesat dalam kurun waktu Tahun 1994 sampai dengan 2008. Lahan terbangun/permukiman, lahan pertanian, dan tambak atau kolam mengalami pertambahan luas, sedangkan penutup lahan berupa hutan/kebun campuran mengalami pengurangan luas. Tabel 
3 menunjukkan luas masing-masing penggunaan/ penutup lahan pada Tahun 1994, 2001 dan 2008, sedangkan Tabel 4 menunjukkan perubahan penggunaan/penutup lahan pada setiap jenis tanah pada Tahun 1994, 2001 dan 2008 .

Tabel 3. Perubahan Penggunaan/Penutup Lahan di DAS Garang

\begin{tabular}{|l|c|c|c|}
\hline \multirow{2}{*}{\begin{tabular}{c}
\multirow{2}{*}{$\begin{array}{c}\text { Penggunaan/Penutup } \\
\text { Lahan }\end{array}$} \\
\cline { 2 - 4 }
\end{tabular}} & \multicolumn{3}{|c|}{$\begin{array}{c}\text { Luas Penggunaan Lahan } \\
\text { (km2) }\end{array}$} \\
\cline { 2 - 4 } $\begin{array}{l}\text { Permukiman/Lahan } \\
\text { Terbangun }\end{array}$ & $\mathbf{1 9 9 4}$ & $\mathbf{2 0 0 1}$ & $\mathbf{2 0 0 8}$ \\
\hline Lahan Pertanian & 49,92 & 34,03 & 48,82 \\
\hline Hutan/Kebun Campur & 134,33 & 102,957 & 85,78 \\
\hline Kolam/Tambak & 0,76 & 1,14 & 1,64 \\
\hline Luas Total & 205,61 & 205,61 & 205,61 \\
\hline
\end{tabular}

Sumber: Analisis Sistem Informasi Geografis

Tabel 4. Perubahan Penggunaan/Penutup Lahan pada Masing-Masing Jenis Tanah

\begin{tabular}{|c|c|c|c|c|c|c|}
\hline No & Jenis Penutup Lahan & Tekstur & $\begin{array}{c}\text { Jenis } \\
\text { Tanah }\end{array}$ & $\begin{array}{c}\text { Luas } \\
\left(\mathrm{km}^{2}\right) \\
\text { Tahun } \\
1994\end{array}$ & $\begin{array}{c}\text { Luas } \\
\left(\mathbf{k m}^{2}\right) \\
\text { Tahun } \\
2001\end{array}$ & $\begin{array}{c}\text { Luas } \\
\left(\mathrm{km}^{2}\right) \\
\text { Tahun } \\
2008\end{array}$ \\
\hline 1 & Lahan Pertanian & $\begin{array}{l}\text { Pasir, pasir } \\
\text { bergeluh }\end{array}$ & B & 2,56 & 1,48 & 0,33 \\
\hline 2 & Lahan Pertanian & Lempung Lanau & $\mathrm{D}$ & 44,05 & 64,72 & 68,66 \\
\hline 3 & Lahan Pertanian & Pasir dan gravel & $\mathrm{A}$ & 2,21 & 1,19 & 0,27 \\
\hline 4 & $\begin{array}{l}\text { Permukiman/Lahan } \\
\text { Terbangun }\end{array}$ & $\begin{array}{l}\text { Pasir, pasir } \\
\text { bergeluh }\end{array}$ & B & 5,98 & 7,02 & 8 \\
\hline 5 & $\begin{array}{l}\text { Permukiman/Lahan } \\
\text { Terbangun }\end{array}$ & Lempung Lanau & $\mathrm{D}$ & 13,44 & 24,46 & 37,28 \\
\hline 6 & $\begin{array}{l}\text { Permukiman/Lahan } \\
\text { Terbangun }\end{array}$ & Pasir dan gravel & A & 2,18 & 2,52 & 3,29 \\
\hline 7 & Hutan/Kebun Campur & $\begin{array}{l}\text { Pasir, pasir } \\
\text { bergeluh }\end{array}$ & B & 0,01 & 0 & 0 \\
\hline 8 & Hutan Kebun Campur & Lempung Lanau & $\mathrm{D}$ & 127,29 & 95,59 & 78,63 \\
\hline 9 & Hutan Kebun Campur & Pasir dan gravel & $\mathrm{A}$ & 6,87 & 7,23 & 7,23 \\
\hline 10 & Kolam/Tambak & $\begin{array}{l}\text { Pasir, pasir } \\
\text { bergeluh }\end{array}$ & B & 0 & 0,06 & 0,23 \\
\hline 11 & Kolam/Tambak & Pasir dan gravel & A & 0,75 & 1,07 & 1,41 \\
\hline
\end{tabular}

Sumber: Analisis Sistem Informasi Geografis

Perubahan penggunaan/penutup lahan paling banyak terdapat di bagian tengah dan hilir DAS Garang. Perubahan penggunaan lahan menjadi lahan permukiman paling banyak terjadi di bagian hilir dan bagian tengah yang terdapat pada jalur Yogyakarta-Semarang. Selain itu Gambar 3 menunjukkan bahwa lahan hutan dan kebun campuran yang tersisa berada di hulu DAS Garang yang merupakan lereng tengah dan atas Gunungapi Ungaran. 

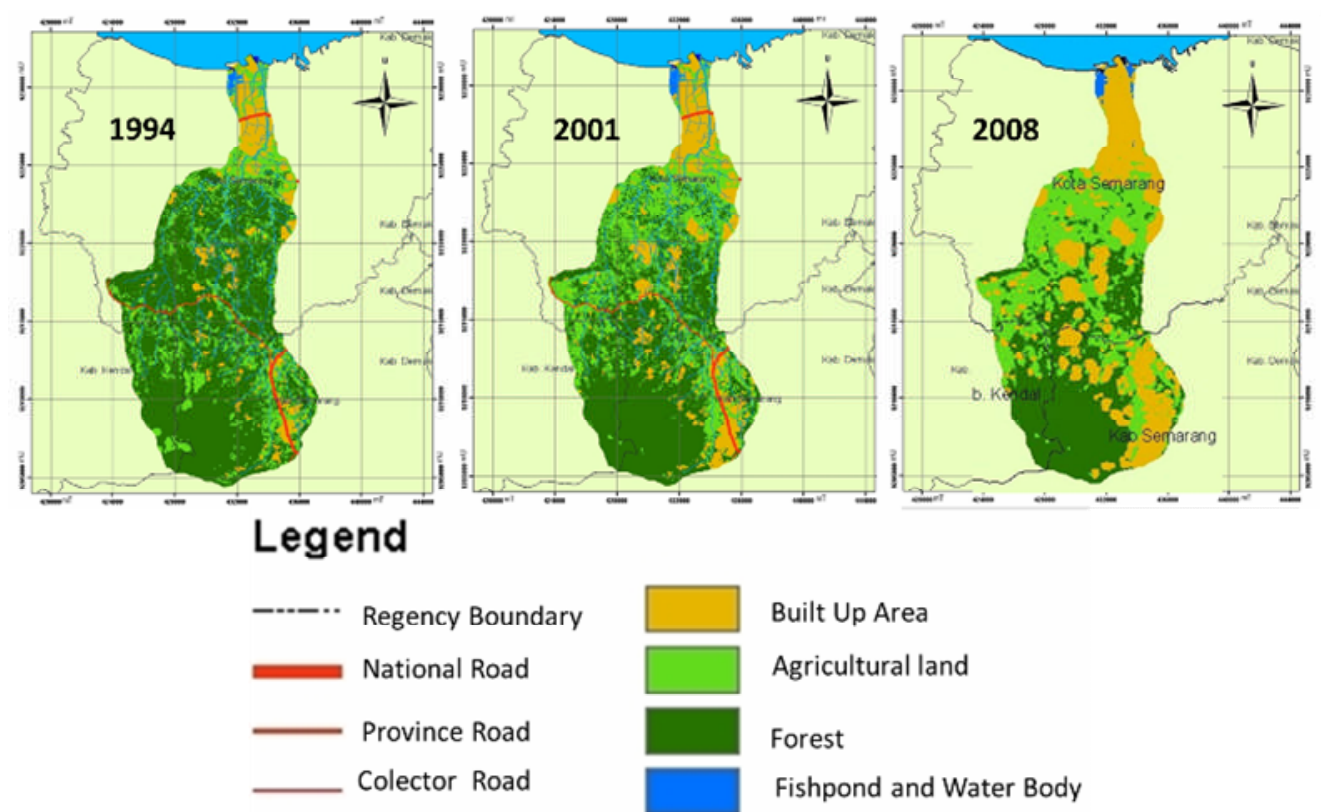

Built Up Area

Agricultural land

Forest

Fishpond and Water Body

Gambar 3. Peta Perubahan Penggunaan/Penutup Lahan di DAS Garang, Jawa Tengah

Perubahan penggunaan/penutup lahan yang terjadi di DAS Garang menyebabkan nilai curve number (CN) meningkat (Gambar 4). Nilai CN menunjukkan jumlah dalam persen dari hujan yang menjadi aliran permukaan. Hal ini berarti bahwa semakin tinggi nilai CN maka jumlah aliran permukaan akan semakin banyak. Hal tersebut kemudian menyebabkan jumlah retensi air oleh tanah akan semakin kecil seperti yang ditunjukkan oleh Gambar 5. Jumlah retensi air pada kondisi kering akan lebih banyak karena pori-pori tanah masih banyak terisi udara yang dapat digantikan oleh air, sedangkan nilai retensi pada kondisi basah akan semakin kecil karena pori-pori tanah telah terisi air sehingga jumlah air yang dapat masuk sedikit. Hal ini akan berakibat pada semakin tingginya tingkat kerawanan banjir bandang di DAS Garang.

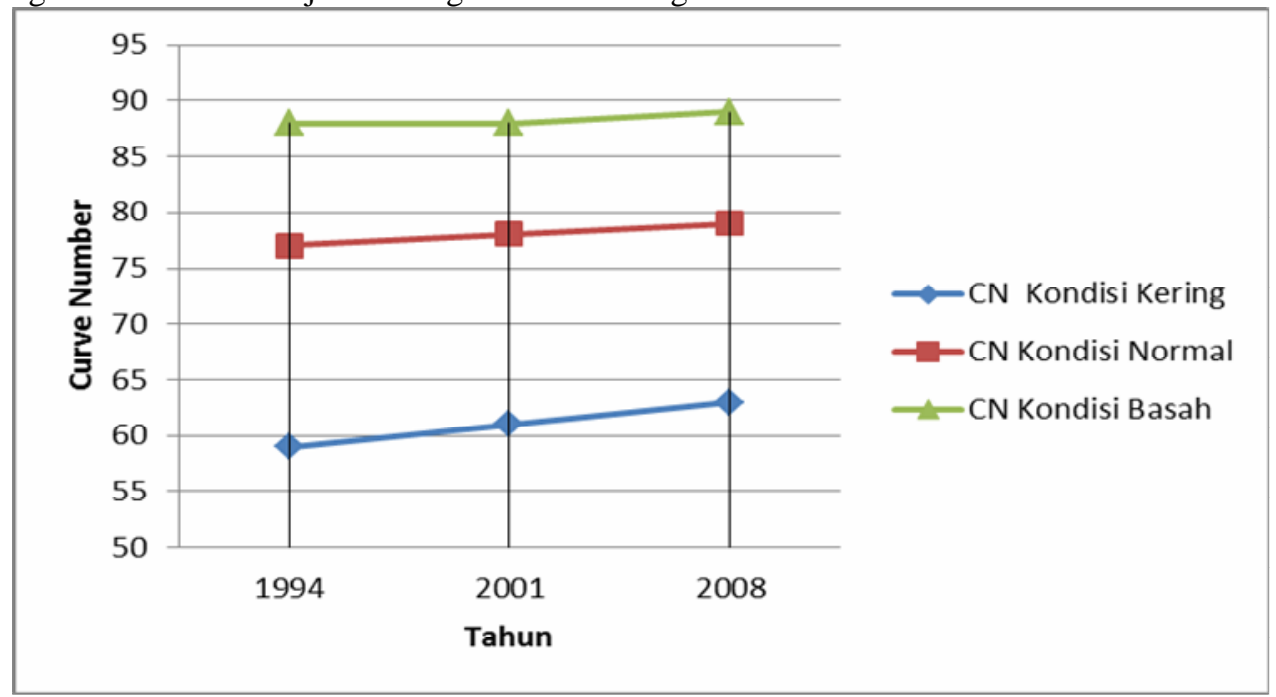

Gambar 4. Perubahan nilai Curve Number di DAS Garang 


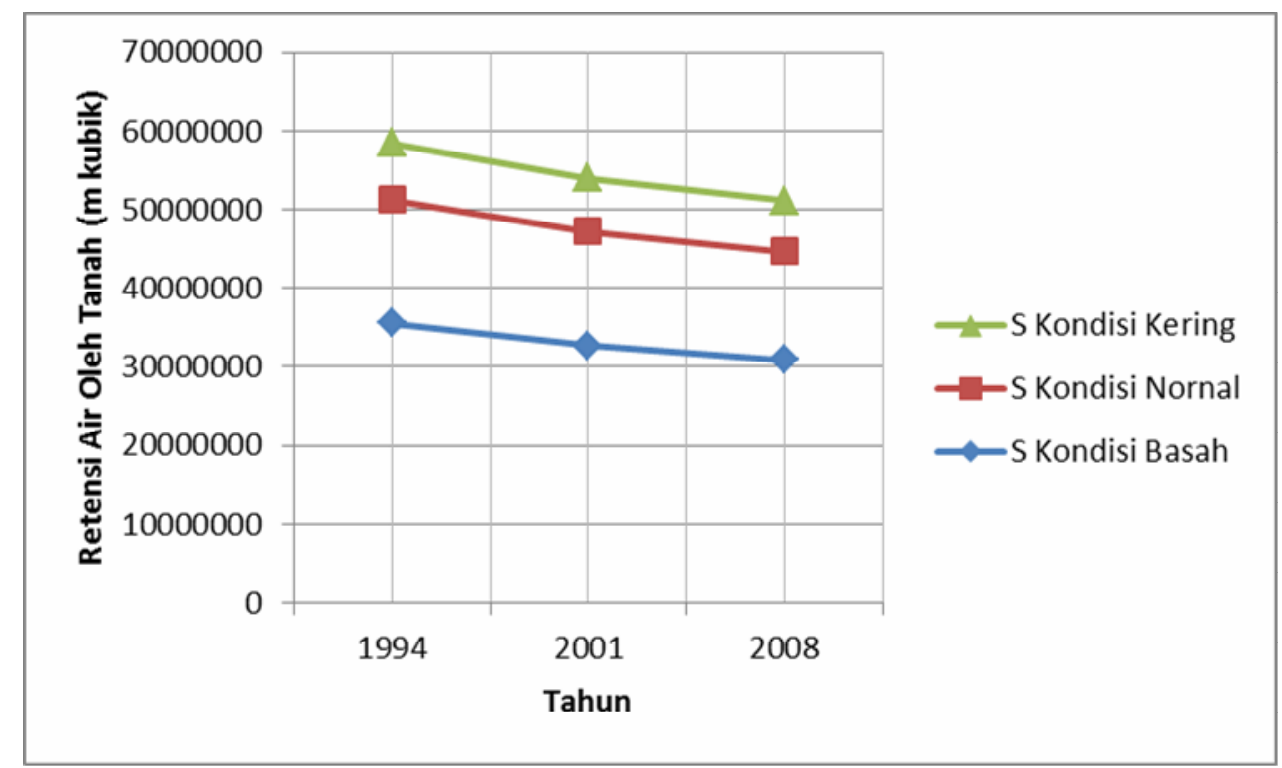

Gambar 4. Perubahan Nilai Resesi Air oleh Tanah di DAS Garang

\section{PENUTUP}

Hasil penelitian ini menunjukkan bahwa perubahan penggunaan dan penutup lahan telah terjadi dengan cukup pesat di DAS Garang dalam kurun waktu Tahun 1994 sampai dengan 2008. Penggunaan lahan yang mengalami penambahan luas adalah permukiman, lahan pertanian dan tambak, sedangkan penutup lahan berupa hutan terus mengalami penurunan luas. Kondisi tersebut menyebabkan semakin besarnya nilai curve number $(\mathrm{CN})$ dan semakin kecilnya nilai retensi air oleh tanah pada kondisi hujan sesaat. Kondisi ini akan meningkatkan kerawanan banjir bandang di DAS Garang.

\section{DAFTAR PUSTAKA}

Bondelid, T.R.; McCuen, R.H. dan Jackson, T.J. 1982. Sensitivity of SCS Methods Models to Curve Number Variation. Journal of the American Water Resources Association, Vol. 18 (1). Hal: 111-116.

Brath, A.; Montanari,A. and Moretti, G. 2006. Assessing The Effect on Flood Frequency of Land Use Change Via Hydrological Simulation (With Uncertainty). Journal of Hydrology, Volume 324. Pp 141-153.

Butler, D. dan Davies, J. W. 2011. Urban Drainage, Third Edition. New York: Taylor and Francis Group.

Kodoatie, R.J. dan Sugiyanto. 2002. Banjir: Beberapa Penyebab dan Metode Pengendaliannya dalam Perspektif Lingkungan. Yogyakarta: Pustaka Pelajar.

Maryono, A. 2007. Restorasi Sungai. Yogyakarta: Gadjah Mada University Press.

McCuen, R.H. 1982. A Guide to Hydrologic Analysis Using SCS Methods. Englewood Cliffs, New Jersey: Prentice-Hall, Inc.

Ragan, R. M. dan T.J. Jackson. 1980. Runoff Synthesis Using Landsat and SCS Model. Journal of Hydrology, Division., ASCE, Vol. 106 (HYS5). Hal: 667-670.

Slack, R.B. \& Welch, R. 1980. Soil Conservation Service Runoff Curve Number Estimates from Landsat Data. Bulletin Water Resources, Vol. 16. Hal: 887-893.

Suhandini, P. 2012. Banjir Bandang di DAS Garang, Semarang, Jawa Tengah. Makalah dalam Seminar Nasional Penginderaan Jauh dan Sistem Informasi Geografis 2012, Fakultas Geografi Universitas Muhammadiyah Surakarta, 21 Januari 2012.

Soerjani, M.; Ahmad, R. dan Munir, R. 2008. Lingkungan: Sumberdaya Alam dan kependudukan Dalam Pembangunan. Jakarta: Penerbit Universitas Indonesia.

Triadmodjo, B. 2008. Hidrologi Terapan. Yogyakarta: Beta Offset.

Windarto, Joko, 2010. Flood Early Warning System Develop at Garang River Semarang using Information Technology base on SMS and Web. International Journal Of Geomatics And Geosciences Volume 1(1). 